\title{
Endoscopic Endonasal Approach to Foramen Magnum Meningioma-Technical Note and Case Example
}

\section{Acesso endoscópico endonasal para meningioma do forame magno-nota técnica e exemplo de caso}

\author{
Flavio Ramalho Romero ${ }^{1}$ Rodolfo Brum Vieira ${ }^{2}$ Bruno da Costa Ancheschi ${ }^{2}$ \\ ${ }^{1}$ Department of Neurology, Psychiatry and Psychology, Faculty of \\ Medicine, Universidade Estadual Paulista Júlio de Mesquita Filho, \\ Botucatu, SP, Brazil \\ 2 Instituto do Cérebro e da Coluna de Botucatu, Botucatu, SP, Brazil \\ Address for correspondence Flavio Ramalho Romero, MD, MSc, PhD, \\ Departamento de Neurologia, Psiquiatria e Psicologia, Faculdade de \\ Medicina de Botucatu da Universidade Estadual Paulista Júlio de \\ Mesquita Filho, 18618970, Distrito de Rubião Júnior, Botucatu, SP, \\ Arq Bras Neurocir 2018;37:362-366. \\ Brazil (e-mail: frromero@ig.com.br).
}

\begin{abstract}
Keywords

- foramen magnum meningioma

- craniocervical junction

- endoscopic endonasal approach

\section{Resumo}

\section{Palavras-chave}

- meningioma do forame magno

- transição craniocervical

- acesso endoscópico endonasal

Foramen magnum (FM) tumors represent one of the most complex cases for the neurosurgeon, due to their location in a very anatomically complex region surrounded by the brainstem and the lower cranial nerves, by bony elements of the craniocervical junction, and by the vertebrobasilar vessels. Currently, the open approach of choice is a lateral extension of the posterior midline approach including far lateral, and extreme lateral routes. However, the transoraltranspharyngeal approach remains the treatment of choice in cases of diseases affecting the craniocervical junction. For very selective cases, the endoscopic endonasal route to this region is another option. We present a case of a ventral FM meningioma treated exclusively with the endoscopic endonasal approach.

Tumores da região do forame magno (FM) representam um dos mais complexos desafios para os neurocirurgiões, devido às lesões estarem localizadas em uma região anatomicamente complexa, composta por elementos ósseos da transição crâniocervical, pelo sistema vascular vertebrobasilar, pelos nervos cranianos baixos e por elementos do tronco cerebral. $\mathrm{O}$ acesso cirúrgico aberto mais utilizado nos dias atuais é uma extensão dos acessos posteriores da linha média, incluindo vias laterais e extremo laterais. Entretanto, o acesso transoral transfaríngeo permanece o tratamento de escolha para uma variedade de doenças que afetam a junção crânio-cervical. Uma alternativa para casos muito bem selecionados é a via endoscópica endonasal para a região. Apresentamos um caso de meningioma de FM tratado exclusivamente por meio de acesso endoscópico endonasal.
\end{abstract}

\section{Introduction}

Foramen magnum meningioma (FMM) comprises only between 1.1 and $3.8 \%$ of all brain and spinal cord tumors. Although it is a very slow growing lesion, the FMM poses significant challenges to the neurosurgeon. ${ }^{1,2}$ Symptoms are often produced by mass effect of the surrounding structures, such as the brainstem, the upper cervical spinal cord, the lower cranial nerves, and the vertebral artery. ${ }^{3,4}$ Anterior or anterolateral lesions of the foramen magnum (FM) region require an approach that allows a good visualization of the lesion without the manipulation of the neural or vascular regional structures. Currently, the far lateral is considered the safest open neurosurgical approach for excising FM lesions. ${ }^{5-9}$ received

April 30, 2018

accepted

July 10, 2018

published online

October 11, 2018
DOI https://doi.org/

$10.1055 / \mathrm{s}-0038-1673428$ ISSN $0103-5355$.
Copyright $\odot 2018$ by Thieme Revinter

Publicações Ltda, Rio de Janeiro, Brazil
License terms

c) $(1) \$$ 
In the last decades, skull base surgeons have been exploring alternate anterior approaches to the FM and to the lower clivus region, such as the transoraltranspharyngeal route. ${ }^{10,11}$ Besides this approach, there is the direct route, with excellent visualization of the FM lesion, which has some disadvantages, such as incomplete resections for tumors extending laterally, craniocervical instability, and cerebrospinal fluid (CSF) leakage with infections. ${ }^{12-14}$ Although the extended endoscopic endonasal approach is most commonly used to treat the upper to middle clivus and the suprasellar regions, the FM can also be reached. ${ }^{15-19}$ Here, we describe a case of FMM that was totally resected with an endoscopic endonasal approach.

\section{Case}

A 39-year-old female was admitted with a 6-month history of paresthesia in 4 extremities and a 5-month history of bilateral lower extremity weakness. On admission, the $10^{\text {th }}$ cranial nerve was impaired bilaterally and the function of the left $12^{\text {th }}$ cranial nerve was also disturbed. Also, spastic tetraparesis was observed, worst in the left lower and right upper extremities. Before being referred to our institution, a protective tracheostomy was performed, and the patient also was on a nasoenteral feeding tube. A magnetic resonance imaging (MRI) exam revealed an anterior foramen meningioma with an important compression of the brainstem and of the craniocervical junction (-Fig. 1). After the case was discussed in our group, an endoscopic endonasal approach was proposed to the patient.

The patient was operated on in the prone position under general anesthesia. A lumbar drain was placed before the main procedure. The surgical procedure was performed using rod lens endoscopes (4 $\mathrm{mm}$ in diameter, $18 \mathrm{~cm}$ in length, $0^{\circ}$ scope) with a high-definition camera. Also, a neuronavigation system and fluoroscopy were available.
First, we drilled out the maxillary crest to provide a lower exposure of the ventral craniocervical junction. Then, after identification of the lower part of the clivus and of the anterior $\mathrm{C} 1$ tubercle by anatomical relationships, an initial linear incision was made in the midline of the nasopharyngeal mucosa. After the subperiosteal dissection, all efforts were made to expose the region as laterally as possible, showing the middle part of both occipital condyles (-Fig. 2A). Using a combination of high-speed drill, bone curette and standard Kerrison rongeurs, the lower part of the clivus, the superior part of the $\mathrm{C} 1$ arch and the medial face of both occipital condyles were carefully removed with bleeding control (-Fig. 2B).

After this extended bone removal, the dura mater was initially opened with a linear middle line incision using a micro-knife, and then a soft tissue tumor was observed (-Fig. 2C). The opening was completed under visualization, and the tumor was carefully dissected from the brainstem and, the most important and dangerous part, from the vertebral arteries (-Fig. 2D e 2E). Note that the right vertebral artery was partially encased by the tumor (-Fig. 2F). After that, the whole lesion was removed (-Fig. 2G) and a 30 and a $45^{\circ}$ scopes were used to make an inspection for residual lesions.

Subsequently, the closure was performed with a dural membrane, fat $(2 \mathrm{H})$, fascia lata (2I) and a dural sealant. Additionally, the lumbar drain was kept open for 60 hours after the surgery, and all signs of CSF leakage were exhaustively evaluated for 7 days. She was discharged 8 days after the surgery without signs of CSF leakage, with mild improvement of weakness, and with physical therapy and rehabilitation for dysphasia. On the third postoperative day, she underwent an MRI, without residual lesions or any sign of acute complications (-Figure $\mathbf{3}$ ).
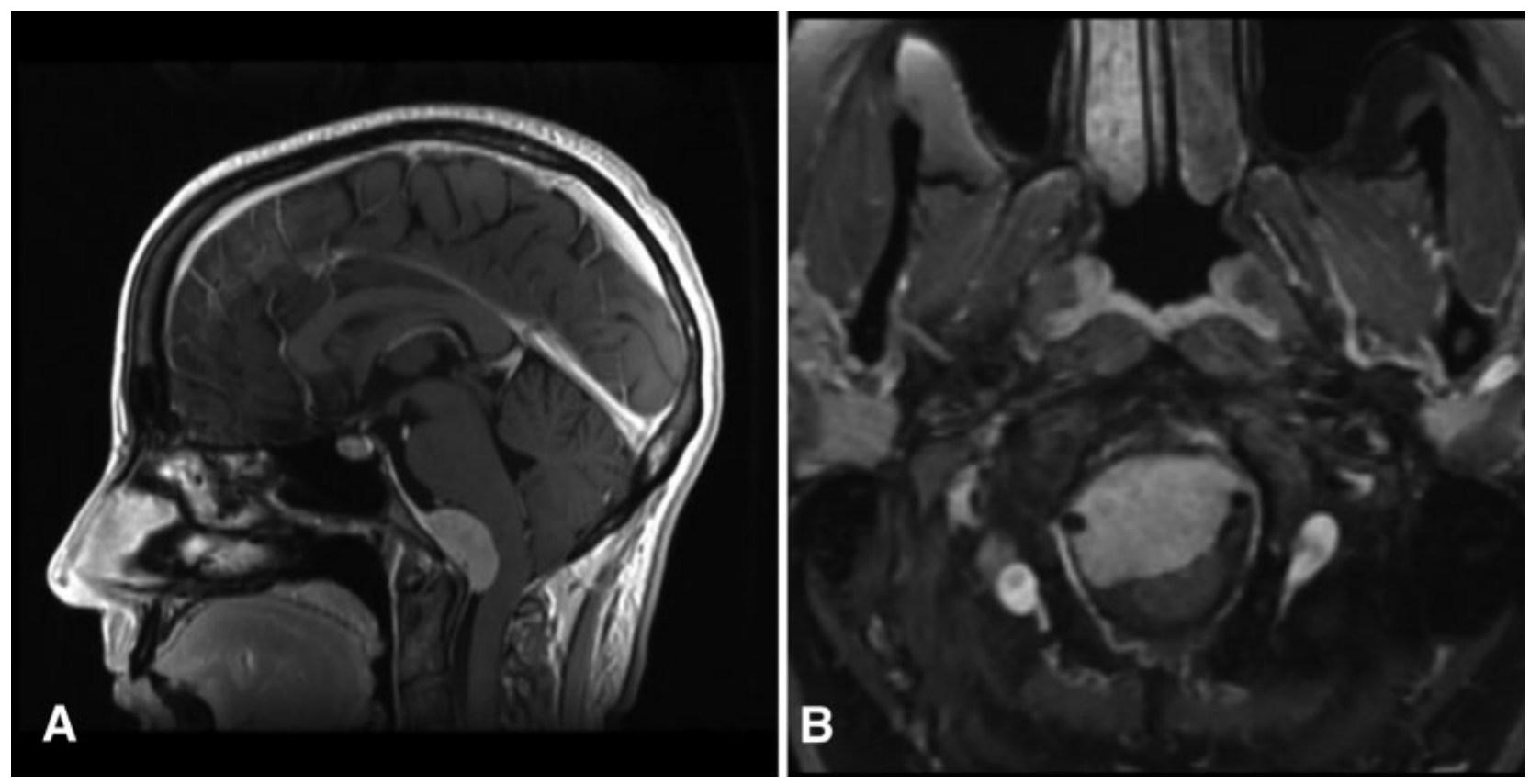

Fig. 1 (A) Preoperative sagittal gadolinium T1 magnetic resonance imaging. (B) Preoperative axial gadolinium T1 magnetic resonance imaging. 

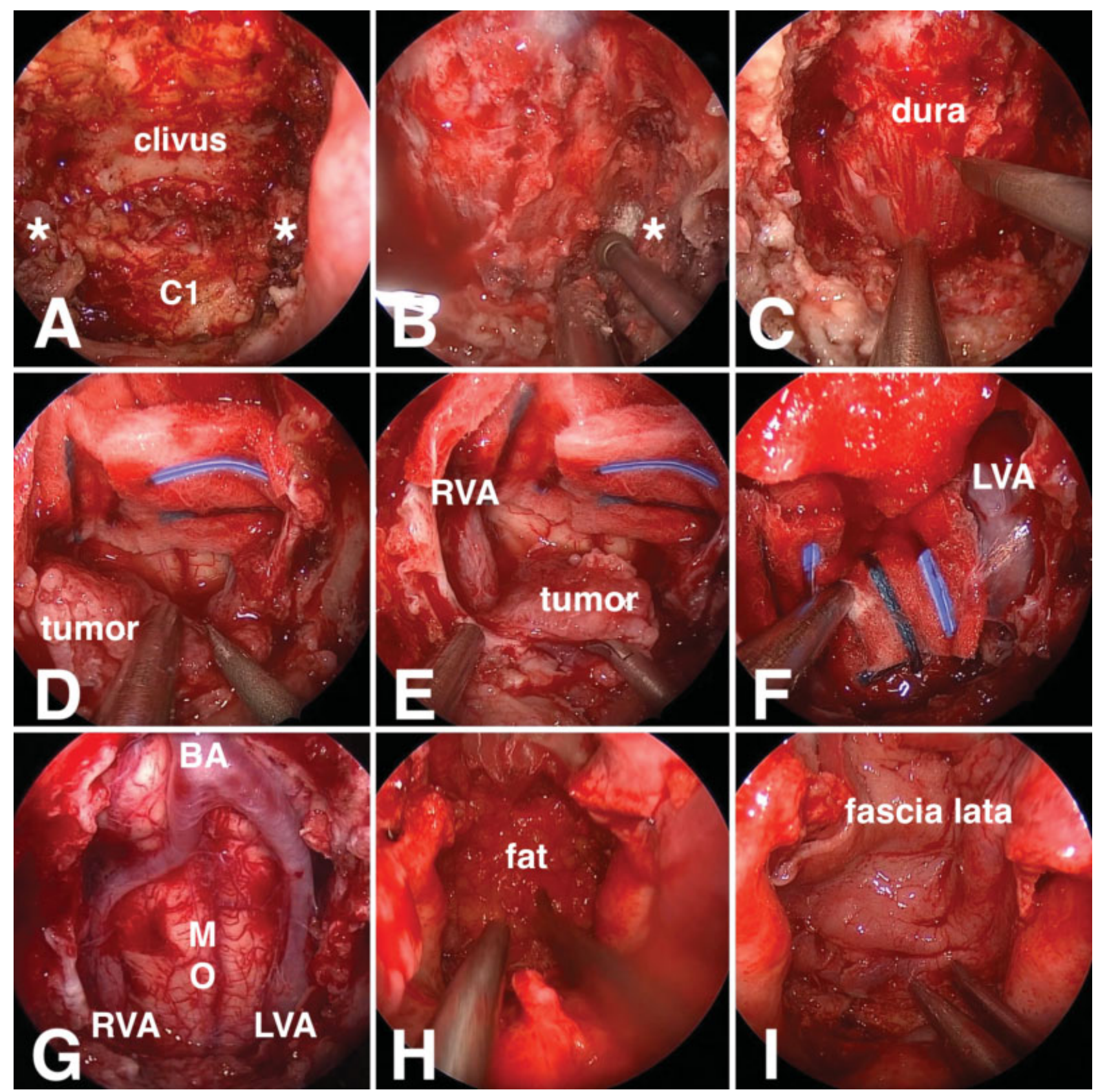

Fig. 2 Intraoperative endoscopic endonasal approach view. (A) Exposure of the anterior structures of the craniocervical junction, focusing on the clivus and on the anterior C1 arch. (B) Drilling the medial face of the occipital condyle. (C) Initial dura opening. (D) Superior face of tumor dissection. (E) Tumor dissection of the right vertebral artery. (F) Tumor dissection of the left vertebral artery. (G) Final aspect after complete removal of the tumor, showing the brainstem, the upper cervical spinal cord, the right and left vertebral arteries, and the basilar artery. $(\mathrm{H})$ Closure with fat. (I) Closure with fascia lata. ${ }^{*}$ occipital condyle; RVA, right vertebral artery; LVA, left vertebral artery; BA, basilar artery; MO, medulla oblongata.

\section{Discussion}

Hallopeau made the first description of a FMM in 1872 presenting these lesions as a challenge to surgical excision. ${ }^{20-23}$ Frazier et al reported the first successful FMM resection in $1922 .{ }^{24}$ The developments of microneurosurgical techniques and modern skull base approaches have allowed an improvement in the results with an acceptable risk in most cases.

Our patient had an anterior FMM. Therefore, the best option was to approach the lesion anteriorly, by a transoraltransphar- yngeal or endoscopic endonasal route. Our choice was based in our experience in endoscopic endonasal expanded skull base surgeries and in our access to all the instruments needed for the procedure. The great advantage of the technique was the direct view of the lesion without manipulation of the brainstem. Also, a good exposure of the inferior clivus and of the anterior arch of the $\mathrm{C} 1$ was necessary to have control of the vertebral arteries. Our big challenge was the closure, because of the great CSF leakage rate reported in the literature and of the controversy about what is the best technique to close. We have chosen a 

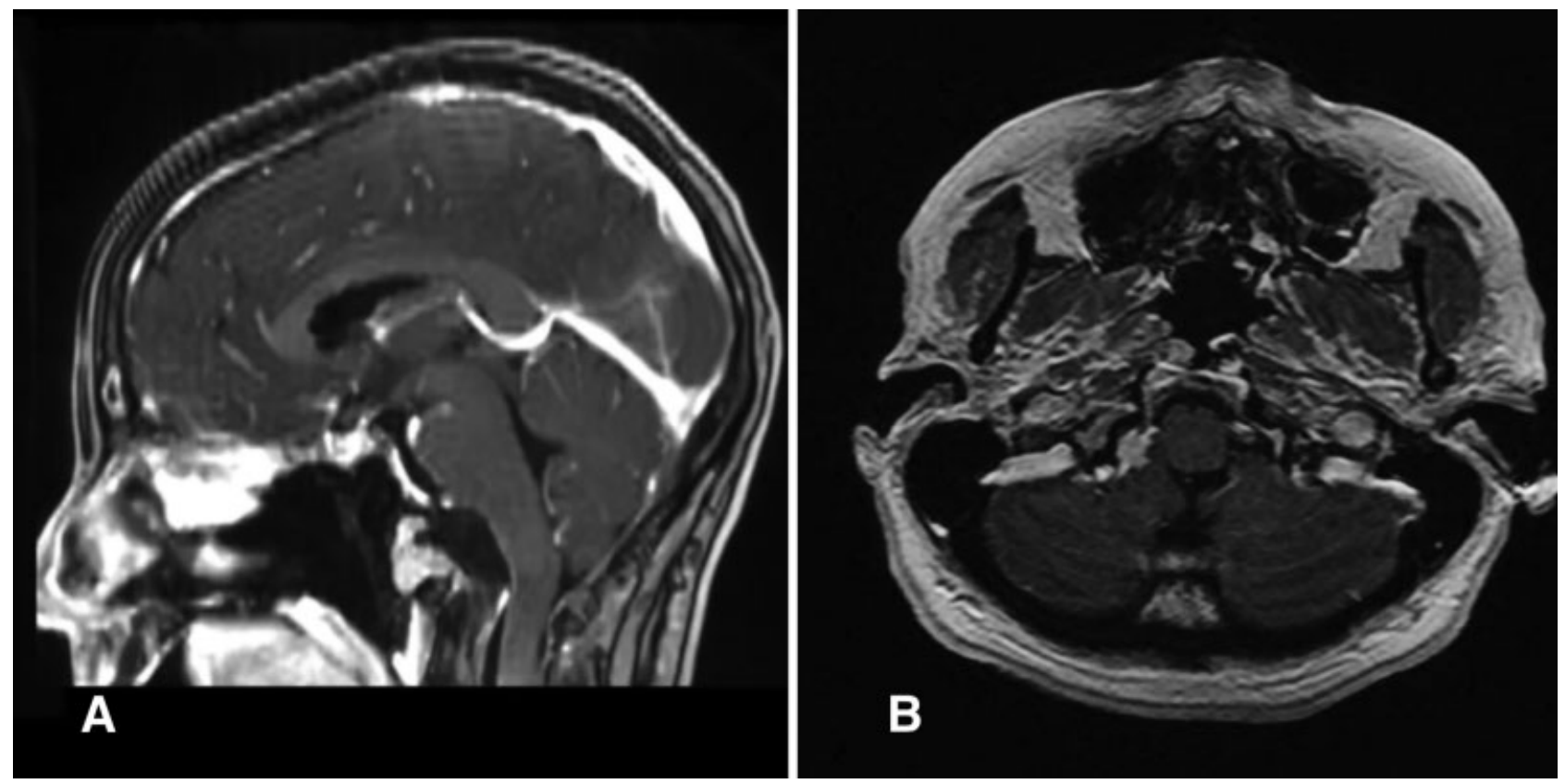

Fig. 3 (A) Postoperative sagittal gadolinium T1 magnetic resonance imaging. (B) Postoperative axial gadolinium T1 magnetic resonance imaging.

multilayer closure with a synthetic dural membrane, fat of the patient, fascia lata and a dural sealant. Also, we kept a lumbar drain for 60 hours after the procedure.

The transoraltranspharyngeal surgical approach provides a direct view of the tumor without retraction of the brain stem. It consists of a classical technique indicated for the management of ventral lesions at the clivus, in the $\mathrm{C} 1$ and in the C2. However, this is a very demanding approach with disadvantages, due to CSF leakage, to the necessity of fusion to restore the stability in the in craniocervical junction, to the narrow working space, to the inadequate lateral view of the tumor, and to the difficult vascular control of the vertebral arteries. $^{25-28}$

An alternative in case of failure of the endoscopic endonasal approach was a far-lateral route. In the past, surgical approaches to anterior FM lesions were through the posterior midline, requiring significant brainstem retraction with high morbidity and mortality rates. The far-lateral approach is a lateral extension of the retrosigmoid approach to facilitate the visualization of and the access to the anterior portion of the FM by the opening of occipital bone, of the $\mathrm{C} 1$, and of the occipital condyle. ${ }^{25,26}$

The endoscopic endonasal approach has been considered an option for transoraltranspharyngeal approach in very selective cases. Most specialists in endoscopic endonasal skull base techniques suggest this route for small to medium-sized midline lesions without significant neurovascular involvement, ${ }^{29,30}$ as we observed in the present case.

While there are many anatomical studies detailing the possibility of using this approach to remove anterior FM tumors, we have not found any specific study on this issue. Also, future studies will be necessary to evaluate the use of this approach to FM lesions, comparing results and complications with other techniques, as the transoral, the farlateral, and even the transcervical.
Conflicts of Interest

The authors have no conflicts of interest to declare.

\section{References}

1 Meyer FB, Ebersold MJ, Reese DF. Benign tumors of the foramen magnum. J Neurosurg 1984;61(01):136-142

2 Love JG, Thelen EP, Dodge HW Jr. Tumors of the foramen magnum. J Int Coll Surg 1954;22(11):1-17

3 Guidetti B, Spallone A. Benign extramedullary tumors of the foramen magnum. Surg Neurol 1980;13(01):9-17

4 Yasuoka S, Okazaki H, Daube JR, MacCarty CS. Foramen magnum tumors. Analysis of 57 cases of benign extramedullary tumors. J Neurosurg 1978;49(06):828-838

5 Goel A, Desai K, Muzumdar D. Surgery on anterior foramen magnum meningiomas using a conventional posterior suboccipital approach: a report on an experience with 17 cases. Neurosurgery 2001;49(01):102-106, discussion 106-107

6 Gupta SK, Sharma BS, Khosla VK, Mathuria SN, Pathak A, Tewari MK. Far lateral approach for foramen magnum lesions. Neurol Med Chir (Tokyo) 2000;40(01):48-52, discussion 52-54

7 Rhoton AL Jr. The far-lateral approach and its transcondylar, supracondylar, and paracondylar extensions. Neurosurgery 2000;47 (3, Suppl)S195-S209

8 Bruneau M, George B. Foramen magnum meningiomas: detailed surgical approaches and technical aspects at Lariboisière Hospital and review of the literature. Neurosurg Rev 2008;31(01):19-32, discussion 32-33

9 de Oliveira E, Rhoton AL Jr, Peace D. Microsurgical anatomy of the region of the foramen magnum. Surg Neurol 1985;24(03): 293-352

10 Samii M, Klekamp J, Carvalho G. Surgical results for meningiomas of the craniocervical junction. Neurosurgery 1996;39(06):1086-1094, discussion 1094-1095

11 Pirotte B, David P, Noterman J, Brotchi J. Lower clivus and foramen magnum anterolateral meningiomas: surgical strategy. Neurol Res 1998;20(07):577-584

12 Wen HT, Rhoton AL Jr, Katsuta T, de Oliveira E. Microsurgical anatomy of the transcondylar, supracondylar, and paracondylar extensions of the far-lateral approach. J Neurosurg 1997;87(04): 555-585 
13 Kassam A, Snyderman CH, Mintz A, Gardner P, Carrau RL. Expanded endonasal approach: the rostrocaudal axis. Part II. Posterior clinoids to the foramen magnum. Neurosurg Focus 2005;19(01):E4

14 Crockard HA. The transoral approach to the base of the brain and upper cervical cord. Ann R Coll Surg Engl 1985;67(05):321-325

15 Steinmetz MP, Mroz TE, Benzel EC. Craniovertebral junction: biomechanical considerations. Neurosurgery 2010;66(3, Suppl)7-12

16 Koller $\mathrm{H}$, Resch $\mathrm{H}$, Tauber $\mathrm{M}$, et al. A biomechanical rationale for C1-ring osteosynthesis as treatment for displaced Jefferson burst fractures with incompetency of the transverse atlantal ligament. Eur Spine J 2010;19(08):1288-1298

17 Visocchi M, Della Pepa GM, Doglietto F, Esposito G, La Rocca G, Massimi L. Video-assisted microsurgical transoral approach to the craniovertebral junction: personal experience in childhood. Childs Nerv Syst 2011;27(05):825-831

18 Duntze J, Eap C, Kleiber JC, et al. Advantages and limitations of endoscopic endonasal odontoidectomy. A series of nine cases. Orthop Traumatol Surg Res 2014;100(07):775-778

19 Yang SY, Gao YZ. Clinical results of the transoral operation for lesions of the craniovertebral junction and its abnormalities. Surg Neurol 1999;51(01):16-20

20 Hallopeau H. Note sur deux faits de tumeur de mesocephale. Gaz Med (Paris) 1874;3:2

21 Cornelius JF, Kania R, Bostelmann R, Herman P, George B. Transnasal endoscopic odontoidectomy after occipito-cervical fusion during the same operative setting-technical note. Neurosurg Rev 2011;34(01):115-121

22 Gempt J, Lehmberg J, Meyer B, Stoffel M. Endoscopic transnasal resection of the odontoid in a patient with severe brain- stem compression. Acta Neurochir (Wien) 2010;152(03): 559-560

23 Mazzatenta D, Zoli M, Mascari C, Pasquini E, Frank G. Endoscopic endonasal odontoidectomy: clinical series. Spine (Phila PA 1976) 2014;39(10):846-853

24 Frazier $\mathrm{CH}$, Spiller WG. An analysis of fourteen consecutive cases of spinal cord tumor. Arch Neurol Psychiatr (Chicago) 1922; 8:455-501

25 George B, Lot G. Anterolateral and posterolateral approaches to the foramen magnum: technical description and experience from 97 cases. Skull Base Surg 1995;5(01):9-19

26 Akalan N, Seçkin H, Kiliç C, Ozgen T. Benign extramedullary tumors in the foramen magnum region. Clin Neurol Neurosurg 1994;96(04):284-289

27 Baird CJ, Conway JE, Sciubba DM, Prevedello DM, QuiñonesHinojosa A, Kassam AB. Radiographic and anatomic basis of endoscopic anterior craniocervical decompression: a comparison of endonasal, transoral, and transcervical approaches. Neurosurgery 2009;65(6, Suppl)158-163, discussion 63-64

28 Blazier CJ, Hadley MN, Spetzler RF. The transoral surgical approach to craniovertebral pathology. J Neurosci Nurs 1986;18 (02):57-62

29 Visocchi M, La Rocca G, Della Pepa GM, et al. Anterior videoassisted approach to the craniovertebral junction: transnasal or transoral? A cadaver study. Acta Neurochir (Wien) 2014;156(02): 285-292

30 Burns TC, Mindea SA, Pendharkar AV, Lapustea NB, Irime I, Nayak JV. Endoscopic Transnasal Approach for Urgent Decompression of the Craniocervical Junction in Acute Skull Base Osteomyelitis. J Neurol Surg Rep 2015;76(01):e37-e42 